LWSA

PAPER - OPEN ACCESS

Terrorism a Socio-Legal Study of Terrorism Acts in Theperspective of Human Rights and International Humanitarian Law
Author
: Aulia Rosa Nasution
DOI
: 10.32734/lwsa.v1i2.203
Electronic ISSN
: 2654-7066
Print ISSN
: 2654-7058

Volume 1 Issue 2 - 2018 TALENTA Conference Series: Local Wisdom, Social and Arts

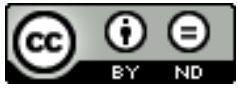

This work is licensed under a Creative Commons Attribution-NoDerivatives 4.0 International License.

Published under licence by TALENTA Publisher, Universitas Sumatera Utara
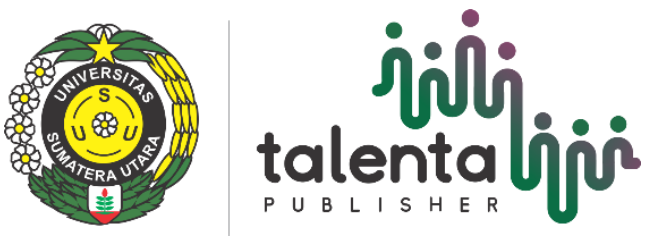


\title{
Terrorism a Socio-Legal Study of Terrorism Acts in Theperspective of Human Rights and International Humanitarian Law
}

\author{
Dr. Aulia Rosa Nasution S.H., M.Hum \\ Lecturer of Postgraduate in Legal Studies at Law Faculty, Medan Area University, \\ Medan, Indonesia
}

nasution82auliarosa@gmail.com

\begin{abstract}
Terrorism has become a worldwide phenomenon in the 21 st century. Acts of terrorism have threatened the human civilization and endangered the peace and the security of mankind. The purpose of this study is to analyze the acts of terrorism as a violation of human rights which will be reviewed from the legal and human rights perspective. The results of this study are show that the acts of terrorism violates the law and human rights at the international level and national level. Terrorism acts also violates the International Humanitarian Law which based on the Geneve Conventions 1949 where many people, civilian or military are the target of the terrorist attacks.
\end{abstract}

Keywords: Acts of Terrorism,Geneve Conventions; Violations of Human Rights; Universal Declaration of Human Rights; Violence

\section{Introduction}

\subsection{Legal concepts of terrorism}

Terrorism has become a global phenomenon since the incidents of September 11 in 2001 which tool place atthe World Trade Centre . There are many definitions of terrorist but no universally accepted definition of terrorism until now, even the United Nation agencies haven't succeeded in making the official definition of terrorism. Noam Chomsky explained that the term of terrorism began to used in the end of the 18th century which refer to the actions of violence from the ruling government in order to ensure that the people will obey the government. In other words ,it refers to coercion from the ruling government.

Historically, the definition of terrorism has been compiled in many international conventions on terrorism that issued by the United Nations. In the article 1 paragraph (2) of the International Convention which issued by the League of Nations 1937 (which was known as the first international convention of terrorism) stated clearly that terrorism is the criminal acts directedagainst a State and intended or calculated to create a state of terror in the minds of particular persons or a group of persons or the general public.

The word of terrorism referring to the system of intimidation and repression implemented by the Jacobins (the " Red Terror' or ' Reign of Terror') in the Frech Revolution. Terrorism also used as an instrument of State control. For example, Bismark "terrorized" Prussia by using the army as a means of social control; NAZI Germany imposed 
reign of terror across Europe and Allied air forces resorted to 'terror bombing' in the Second World War, and Stalin ruled Russia by "terror". Gradually, the term of terrorism also came to refer to non-State practices. In the late of 19th century, revolutionaries and anarchists in tsarist Russia were commonly known as terrorist. The Bolshevik seizure of power is oftend described as revolutionary terror and communist embraced terrorism as a means of class struggle.

Terrorism internationally condemned as the unlawful use and the manifestation of political movement. In October 2004, the UN Security Council unanimously passed Resolution 1566 which defines terrorism and declares that in no circumstances can terrorist acts be condoned or excused for political or ideological reasons as following ; Criminal acts, including those against civilians, committed with the intent to cause death or serious bodily injury or taking of hostages with the purpose to provoke a state of terror in the general public or in a group of persons or particular persons, intimidate a population or compel a government or an international organization to do or to abstain from doing any act, which constitute offences within the scope of and as defined in the international conventions and protocols relating to terrorism, are under no circumstances justifiable by considerations of a political, philosophical, ideological, racial, ethnic, religious or other similar nature.

To understand terrorism in the contemporary context, it is important to recognize that terrorism is generally considered as a tool or a tactic, not as an ideology or philosophy. This "tool" can be used as part of a larger political or military campaign such as an insurgency. When al-Qaeda conducted the 9/11 attacks, it was using the "tool" of terrorism to achieve the larger purposes of diminishing American political influence in the Middle East, among other objectives.

Terrorism can be conceptually and empirically distinguished from other modes of violence and conflict by the following characteristics; a) it is premeditated and designed to create a climate of extreme fear; b) it is directed at a wider target than the immediate victims; c) it inherently involves attacks on random or symbolic targets, including civilians; d) it is considered by the society in which it occurs as 'extra-normal' that violates the norms; e) it is used primarily to influence the political behavior of governments, communities or specific social groups.

A better definition of terrorism can be seen in the International Convention for the Suppression of Terrorist Bombings, 1997 in article 2 paragraph (1) which clearly stated;

Every person commits an offence within the meaning of this Convention if that person unlawfully and intentionally delivers, places, discharges or detonates an explosive or other lethal device in, into or against a place of public use, a State or government facility, a public transportation system or an infrastructure facility: (a) with the intent to cause death or serious bodily injury; or (b) with the intent to cause extensive destruction of such a place, facility or system, where such destruction results in or is likely to result in major economic loss.

The definition of terrorism acts in the UK Legislation was inserted in the UK Terrorism Act , 2000 which clearly stated as following: Terrorism is the use or threat of the action where (a) the action falls within subsection (2) which includes a) involves serious violence against a person; b) involves serious damages to property; c) endangers a person's life, other than that of the person committing the action, d) creates a serious risk to the health or safety of the public or a section of the public; or e) is designed seriously to interfere with or seriously to disrupt an electronic system. (b) Terrorism also means the use or threat which is designed to influence the government or to intimidate the public or a section of the public ; (c) the use or threat is made for the purpose of advancing a political, religious or ideological cause.

The U.S. Legislation distinguished the terrorism definitions to international terrorism and domestic terrorism. The definition of terrorism in the United States contained in 18 U.S. Code 2331 which is stated as following;

The term of "international terrorism" means activities that; a) involve violent acts or acts dangerous to human life that are a violation of the criminal laws of the United States or of any State, or that would be a criminal violation if committed withi the jurisdiction of the United States or of any State; b) appear to be intended; (i) to intimidate or coerce a civilian population; (ii) to influence the policy of a government by intimidation or coercion; or (iii) to affect the conduct of a government by mass destruction, assassination or kidnapping ; and c) occur primarily outside the territorial jurisdiction of the United States or transcend national boundaries in the terms of the means by which they are accomplished, the person they appear intended to intimidate or coerce, or the locale in which their perpetrators operate or to seek asylum. 
The term of "domestic terrorism" means activities that: a) involve acts dangerous to human life that are a violation of the criminal laws of the United States or of any State; b) appear to be intended ; i) to intimidate or coerce a civilian population; ii) to influence the policy of a government by intimidation or coercion; or iii) to affect the conduct of a government by mass destruction, assassination or kidnapping; and c) occur primarily within the territorial jurisdiction of the United States.

From those definitions of terrorism, we can identify several components of terrorism acts as follows ; a) the unlawful force; b) intimidation ; c) coercion; d) the use of threat; e) attacking civilian people; f) motivated by ideological, political and religious things; f) aim to influence the public (audience) ; g) destruct the government facilities; h) conducted by State actors or non-State actors; i) targeting the civilian and military objects; h) cause death or serious bodily injury.

In 2002, the Council of the European Union adopted the 'Framework Decision on Terrorism' which contains a detailed definition specifying a terrorist act as an act which may seriously damage a country or an international organization where committed with the aim of seriously intimidating a population, or unduly compelling a Government or international organization to perform or abstain from performing any act, or seriously destabilizing or destroying the fundamental political, constitutional, economic or social structures of a country or an international organization.

The definition enumerates nine types of terrorist acts, including: a) certain attacks on life and integrity of persons, b) seizure of aircraft and ships, c) kidnapping or hostage taking, d) causing destruction of government property or infrastructure, e) manufacture of what amounts to weapons of mass destruction and c) interfering with a country's resources with the effect of endangering human life.

\subsection{State and Non-State Terrorism}

Generally, acts of terrorism can be classified to 'State Terrorism' and 'Non-State Terrorism'. State Terrorism is a use of terror by a government as an instrument to subjugate other party to achieve governments purposes. R. Tackrah describes the differences between State terror and terrorism in terms of law enforcement by the state versus defiance of the state: "Terror practiced by a government in office appears as law enforcement and is directed against the opposition while terrorism on the other hand implies open defiance of the law and is the means whereby an opposition aims to demoralize government authority.

State Terrorism is likely occurred in the authoritarian and repressive government. In other words, this kind of authoritarian and repressive government always using terror as their instrument to intimidate anyone against their policies. Totalitarian regimes have used huge systems of state terror to control whole populations and to persecute and silence dissidents and those designated 'enemies of the state'. Because this regimes have a monopoly of armed forces and a ruthless secret police apparatus, state terror has been a very effective method of suppressing opposition and resistance.

State Sponsored Terrorism can transformed into transnational crime if a country commits acts of terror against other countries by giving assistance, protection, financing plan, and facilitating terrorist group to other countries. For an example, State Terrorism which was committed during NAZI regime in Germany which led by Adolf Hitler and Joseph Stalin who conducted a totalitarian government in Sovyet Union (Russia) where there so many acts of terror like kidnapping, punishing, torturing, and executing many innocent civilians which creates a tremendous fear.

On the other hand, a 'Non-State Terrorism' is a terror that is used by a non-State actor such as an individual or certain groups of people against the people or government with various motives behind. For example, the terrorist group of Bali Bombing which was led by Imam Samudera, the terrorist group of Noordin M. Top from Jemaah Islamiyah, the terrorist Group of Santoso which conducted many acts of terrorism in Sulawesi, and also the terrorist group of Abu Sayyaf who committed murder and hostages in the south areas of Philippine.

\section{Methodology of the research}

The methodology which isused in this study is a socio-legal research. Socio-legal researchers increasingly recognize the need to employ a wide variety of methods in studying law and legal phenomena and the need to be informed by an understanding of debats about theory and method in mainstream social science. The study in this 
paper shows that terrorism has became a global phenomenon which can be analyzed from a socio-legal perspective. The objective of this methodology is to show how different methods can be used in researching terrorism acts as a legal and social phenomena, how methodological issues in sociology are relevant to the study of law. It also approaches the methodological problem of how the sociology of law can address the content of legal issues.

To further clarify the status and approach of socio-legal studies, we could contrast it with the sociology of law. The sociology of law receives its intellectual imputes mainly from mainstream sociology and aims to transcend the lawyer's focus on legal rules and legal doctrines by remaining 'exogenous to the existing of legal system in terms of the wider social structures'. That is why 'the law, legal prescriptions and legal definitions are not assumed or accepted, but their emergence, articulations and purpose are themselves treated as problematic and worhy of study.

On the other hand, a socio-legal studies, often employs sociology (and other social sciences) not so much for substantive analysis but as a 'tool' for data collection. Nicola Lacey explainsa socio legal study as following;

Socio legal studies I take to be a similarly diverse body of scholarship which is united by two concerns. First, socio legal scholarship legal practices within the context of the other social practices which constitute theirimmediate environment. Thus it comprehends a complex of administrative, commercial, economic, medical , psychiatric and other disciplinary practices, wherever they impinge upon or interact with law. Second, socio legal studies subject legal practices to an empirical inquiry which scrutinizes not merely the legal articulation of the relevan rules and processes but the meaning and effects of those rules and processes as interpreted and enforced, and as experienced by their subject".

Brian Z. Tamanaha in his book "Realistic Socio Legal Theory, Pragmatism and A Social Theory of Law" explains a socio-legal study as following: "The label socio legal studies has generally become a general term encompassing a group of disciplines that applies a social scientific perspective to the study of law, including the sociology of law, legal anthropology, legal history, psychology of law, political science studies of courts and scienc oriented comparativists. These various approaches to law are joined by more that just their scientific orientation. Broadly speaking, the glue with bonds this diverse group is a left to far left critical orientation to law."

From those definitions, we can incorporate socio-legal studies as a form of legal study that uses the social science perspective on law which is done as an internal critique to the law, where the target of criticism is the weakness of the law when it met the social reality. Socio-legal research is a type of a study that represents a way of seeing a law more to the context than the text.

The purpose of the socio-legal method in this study is to analyze the terrorism issues from a socio-legal perspective which involves a legal statutes, legal doctrines, legal conventions, legal measures which also related to the human rights perspective which is examined from thehuman rights charter like thethe Universal Declaration of Human Rights, and the human rights fundamental principles.

\section{Terrorism as Aviolation of Human Rights}

\subsection{Terrorism and human rights}

Mochtar Kusumaatmadja and B. Arief Sidharta has given the general definition of human rights which is stated as a freedom to do something or not to do something related to the subject without interference from any party and those freedoms are recognized and have protected by law and therefore have a legal basis. The human rights norms based on the idea that the people must be freed from the cruel and inhumane acts. Every human has three kinds of human rights, 1) the right to live, 2) the right for freedom, 3) the right to have something.

Terrorism is generally understood as acts of violence which spread terror among the civilians and civilian population. Terrorist use a terror as their weapon. The hijacking and crashing of the aircrafts create terror in the minds of people, especially the direct and indirect victims. Such is the fear created that people now afraid to fly. The Abu Sayyaf kidnappers inspire fear by beheading their hostages. Exploding bombs in public places and killing innocent people inspire fear and terror, and a feeling of being unsafe anywhere at any time.

Terrorism has become a gross violation of human rights which undermines the State and peaceful political processes; and threatens international peace and security. Numerous resolutions of the UN General Assembly since the 1970's, and of the Comission on Human Rights since the 1990's assert that terrorism threatens or destroys basic 
human rights and freedoms, particularly life, liberty and security, but also civil and political and economic, social and cultural rights. Regional anti terrorism instruments such as 1998 Arab Convention,preamble; 1999 OIC Convention, preamble; 1971 OAS Convention, preamble; 1999 OAU Convention, preamble, OAS Declaration of Lima to Prevent, Combat and Eliminate Terrorism, 26 April 1996, preamble also stated that terrorism gravely violates human rights. UN Special Rapporteur observes that there is probably not a single human rights exempt from the impact of terrorism.

The Universal Declaration of Human Rights (UDHR) preamble states that 'freedom from fear' is part of 'the highest aspiration of the common people' while the International Covenant on Civil and Political Rithgs (ICCPR) and the International Covenant on Economic, Social and Political Rights (ICESCR) preambles refer to 'the ideal of free human beings enjoying freedom from fear'. The political ideal of 'freedom from fear' was first articulated as one of four freedoms in a speech by US President Franklin D. Roosevelt in 1941. Franklin D. Roosevelt stated the Four Freedom which was known as "the four freedom speech" (1941 State of the Union Address) where he proposed four fundamental freedoms that people everywhere in the world ought to enjoy as follows; a) freedom of speech, b) freedom of worship,c) freedom from want ; d) freedom from fear.The four freedoms of Roosevelt formed an important pillar of the Universal Declaration of Human Rights that were adopted on December 10, 1948 by United Nation General Assembly. The freedom from fear is mentioned in the preamble of the Declaration.

Universal Declaration of Human Rights is considered as a fundamental human rights document and binding on all states. International human rights law has been codified through major human rights treaties and the remaining portion is available in customary international law. The most important of these treaties are, International Covenant on Economic, Social and Cultural Rights; and the International Covenant on Civil and Political Rights, and its two Optional Protocols.

The Universal Declaration of Human Rights serves as a reminder of the idealistic objectives for the collective good of humanity, in enshrining 'pre-legal' ethical standards, which manifest as rights and freedoms for all of humanity, irrespective of nationality, creed, ethnicity, gender, religious beliefs or any other status.Its declarations act as a "moral guide of world order, governance, moral, and normative standards, international law, and individual interactions". It is distinguished by its unprecedented aspirations to conceive human rights applicable to all in a universal and indivisible fashion. The UDHR has inspired more than 80 international human rights treaties, conventions, and declarations.

Modern human rights standards are rooted in the following four simple values ; a) freedom of want, b) freeom of fear; c) freedom of belief, d) freedom of expression. These freedoms form the core principles of the Universal Declaration of Human Rights which set out the fundamental elements of international human rights accepted United Nations member states and elaborated in many subsequent human rights treaties . This declaration is accepted as "a common standard of achievement for all people and all nations".

Terrorism aims at the very destruction of human rights, democracy and the rule of law. It attacks the values that lie at the heart of the Charter of the United Nations and other international instruments: respect for human rights; the rule of law; rules governing armed conflict and the protection of civilians; tolerance among peoples and nations; and the peaceful resolution of conflict.

Terrorism has a direct impact on the enjoyment of a number of human rights, in particular the rights to life, liberty and physical integrity. Terrorist acts can destabilize governments, undermine civil society, jeopardize peace and security, threaten social and economic development, and may especially negatively affect certain groups. All of these have a direct impact on the enjoyment of fundamental human rights.

The destructive impact of terrorism on human rights and security has been recognized at the highest level of the United Nations, notably the new Human Rights Council which clearly stated acts of terrorism as following : a) threatens the dignity and security of human beings everywhere, endangers or takes innocent lives, creates an environment that destroys the freedom from fear of the people, jeopardizes fundamental freedoms, and aims at the destruction of human rights; b) has an adverse effect on the establishment of the rule of law, undermines pluralistic civil society, aims at the destruction of the democratic bases of society, and destabilizes legitimately constituted Governments; c) has links with transnational organized crime, drug trafficking, money-laundering and trafficking in arms, as well as illegal transfers of nuclear, chemical and biological materials, and is linked to the consequent 
commission of serious crimes such as murder, extortion, kidnapping, assault, hostage-taking and robbery; d) has adverse consequences for the economic and social development of States, jeopardizes friendly relations among States, and has a pernicious impact on relations of cooperation among States, including cooperation for development; and e) threatens the territorial integrity and security of States, constitutes a grave violation of the purpose and principles of the United Nations, is a threat to international peace and security, and must be suppressed as an essential element for the maintenance of international peace and security.

International and regional human rights law makes clear that States have both a right and a duty to protect individuals under their jurisdiction from terrorist attacks. This stems from the general duty of States to protect individuals under their jurisdiction against interference in the enjoyment of human rights. More specifically, this duty is recognized as part of States' obligations to ensure respect for the right to life and the right to security.

The right to life, which is protected under international and regional human rights treaties, such as the International Covenant on Civil and Political Rights, has been described as "the supreme right" because without its effective guarantee, all other human rights would be without meaning. As such, there is an obligation on the part of the State to protect the right to life of every person within its territory and no derogation from this right is permitted, even in times of public emergency. The protection of the right to life includes an obligation on States to take all appropriate and necessary steps to safeguard the lives of those within their jurisdiction. As part of this obligation, States must put in place effective criminal justice and law enforcement systems, such as measures to deter the commission of offences and investigate violations where they occur; ensure that those suspected of criminal acts are prosecuted; provide victims with effective remedies; and take other necessary steps to prevent a recurrence of violations.

In addition, international and regional human rights law has recognized that, in specific circumstances, States have a positive obligation to take preventive operational measures to protect an individual or individuals whose life is known or suspected to be at risk from the criminal acts of another individual,which certainly includes terrorists. Also important to highlight is the obligation on States to ensure the personal security of individuals under their jurisdiction where a threat is known or suspected to exist. This, of course, includes terrorist threats.

\subsection{Terrorism acts as a violation of the international humanitarian law}

The conflict and war issues became contemporary issues in legal studies when many victims of human casualties from war and armed conflict involving victims of civilians as well as victims of military (armed forces). Civilian casualties normatively are not engaged in armed conflict where they should be protected. The International Humanitarian Law (IHL) or so-called "Humanitarian Law" is one of the fields in Law which replaces "Laws of War".

The term of "Laws of War" that always called as "the Laws of Armed Conflict" relating to the issue of war or armed conflict with various problems that surround it both internationally and non-internationally. Gradually this term transformed into "International Humanitarian Law Applicabe in the Armed Conflict". The main purpose of International Humanitarian Law is to provide protection and help for civilians that has become victims, weather they participated in hostilities (combatan) or not participated (non-combatant).

There have been many instruments of International Humanitarian Law which made in the period before the World War II and afterwards. The International Humanitarian Law is apllied under the Geneve Conventions (1949). The Geneva Conventions comprise four treaties, and three additional protocols, that establish the standards of international law for humanitarian treatment in war.The Geneva Conventions extensively defined the basic rights of wartime prisoners (civilians and military personnel); established protections for the wounded and sick; and established protections for the civilians in and around a war-zone. The Additional Protocols of the Geneva Convention, 1949 comprise of two protocol: Protocol I which relating to the protection of victims of International Armed Conflicts, and Protocol II which relating to the protection of victims on Non-International Armed Conflicts.

The Geneva Conventions entered into force on 21 October 1950 and since 2000, 196 countries has ratified this conventions with reservations. Moreover, the Geneva Convention also defines the rights and protections afforded to non-combatants. The Geneva Conventions are rules that apply only in times of armed conflict and seek to protect people who are not or are no longer taking part in hostilities; these include the sick and wounded of armed forces on 
the field, wounded, sick, and shipwreckedmembers of armed forces at sea, prisoners of war, and civilians. The first convention dealt with the treatment of wounded and sick armed forces in the field.The second convention dealt with the sick, wounded, and shipwrecked members of armed forces at sea. The third convention dealt with the treatment of prisoners of war during times of conflict.The fourth convention dealt with the treatment of civilians and their protection during wartime.In a case where terrorism acts occurred in times of armed conflict, the then Geneve Conventions may be applied to determine the persons that should be protected, and at the same time to determine the rights and obligations for those victims (civilians) who are participated (combatant) or not participated (noncombatant) in hostilities.

The International Humanitarian Law distinguishes two types of disputes. The first type is the International Armed Conflicts, secondly is the non-International Armed Conflicts. International Armed Conflict is a war between two or more countries, while non international armed conflicts are combat or war that occurred between a State and nonState fighting groups . Thus if a State fights with a rebel groups, it is regarded as a non-International Armed Disputes even though the fighting took place outside the territory of a country.

The main difference between non-international armed conflict and international armed conflict can be seen from the legal status of the disputing parties. In an intenrational armed conflict both parties have the same legal status because both parties are state entities (entities considered equivalent to the state), while in non-international armed conflicts the status of the two parties is not the same, that is between the countries which are the subject of international law with other non-state parties. On the other hand,the non-international armed conflictcan be seen as a war situation in which there is a battle between the official armed forces of a country against a group of official armed groups of a country against organized armed groups.

The regulation of a non-International Armed Conflicts is contained in the Article 3 of the Additional Protocol (II) ,Geneva Conventions 1949 which determines the rules of International Humanitarian Law and the obligations of conflicting parties to protect victims in non-International disputes . The definition of a non-International Armed Conflicts is contained into Additional Protocol II of 1977 on the Protection of International Victims of Disputes which clearly state that the International Armed Conflicts occurring between the state armed forces and an organized armed groups under a responsible command, exercising control in parts of a territory that enable groups to conduct military operations continuously and to apply the rules of International Humanitarian Law which contained in Article 3 of the Additional Protocol (II), Geneva Conventions 1949.

In recent years, we have seen many acts of terrorism that was conducted by non-State Armed Groups such as AlQaida groups who conducted acts of bombing to the World Trade Centre building, as well as the groups of Jemaah Islamiyah (JI) who participated in the Bali Bombing incident. The Interrational Humanitarian Law prohibits most acts that are criminalized as "terrorist" acts in domestic legislation and international conventions dealing with terrorism. The International Humanitarian Law prohibits both specific acts of terrorism committed in armed conflict and, as war crimes, a range of other acts of violence when committed against civilians or civilian objects.

\section{Conclusion}

The conclusion of this study as following ; first, acts of terrorism constitute a gross violation of human rights where it is committed with the acts of murdering, intimidating, threatening, causing death and injuries and containing violence and the use of force to the innocent people (civilians), conducted and organized well by a State or a Non-State groups, that occurred in a peace time or in a war time, to achieve political, ideological or religious purposes and make it as legitimate means to achieves their goals which showing disrespect and ignoring the fundamental norms of human rights. Secondly acts of terrorismhas become a gross violation of human rights which threatens the most fundamental rights of human being, the rights to live that inherently owned by every individualwhere this rights have been recognized and regulated in the human rights norms on the international and national level. Thirdly, the International Humanitarian Law has becomes one of the branches of law that regulates the International Armed Conflict through the Geneve Conventions, althoughthe International Humanitarian Law does not put the acts of terrorism on its conventions but the provisions of article 3 of the 1977 may be applied to the terrorist acts. In other words, terroris acts constitute a violation to the International Humanitarian Law. 


\section{References}

[1] Ambarwati et.al., 2009, Hukum Humaniter Internasional dalam Studi Hubungan Internasional. Rajawali Press. Jakarta. page. 28

[2] Banakar Reza, et al. Introduction to Theory and Method in Socio-Legal Research, retrieved on September 4 from ps://papers.ssrn.com/sol3/papers.cfm?abstract_id=1511112

[3] Haryomataram, KGPH. 2005. Pengantar Hukum Humaniter. Raja Grafindo Persada. p. 1

[4] Jawab, Saqib. Terrorism and Human Rights, Sociology and Anthropology. 3 (2) : 104 -115, retrieved 15 August 2017 from http://www.hrpub.org

[5] Martin, Gus. 2013. Understanding Terrorism, Challenges, Perspectives and Issues. SAGE Publications, Washington D.C., p.37

[6] Mahsyar, Ali. 2009. Gaya Indonesia Menghadang Terorisme: Sebuah Kritik Atas Kebijakan Hukum Pidana TerhadapTindak Pidana Terorisme di Indonesia. Penerbit: MandarMaju, Bandung, p. 49

[7] Mohammad, Mahathir. 2003. Terrorism and The Real Issues, Mahathir Mohammad, Pelanduk Publications, Malaysia.

[8] Rusman, Rina, 2009, Jenis-jenis Sengketa Bersenjata dan Implikasinya Dalam Hubungan Internasional dan Pemberlakuan Hukum Humaniter Internasional, Rajawali Press: Jakarta, p.53

[9] Sabon, Max Boli, 2014. Hak Asasi Manusia Bahan Pendidikan untuk Perguruan Tinggi. Universitas Atmajaya. p. 14

[10] Sefriani. 2010. Hukum Internasional Suatu Pengantar. Rajawali Press: Jakarta p. 367.

[11] Sidharta. 2016. Socio-Legal in the Development of Legal Research Method in Interdisipliner Methodology,An Introduction to Socio-Legal, Thafamedia, Yogjakarta, p. 44.

[12] Tackrah, R. 1987.Terrorism: A Definitional Problem, in Contemporary Research on Terrorism, ed. Paul Wilkinson and Alasdair M. Stewart , Aberdeen University Press, UK, ,p.

[13] Wilkinson, Paul, 2011, Terrorism versus Democracy, Routledge, Taylor and Francis Group, Third Edition, p.4.

[14] Countering Terrorism Protecting Human Rights : A Manual, OSCE \& Office for Democratic Institutions and Human Rights (ODIHR), retrieved on 17 August, 2017 http://www.osce.org/odihr/29103?download=true

[15] Office of the United Nations High Commissioner for Human Rights, "Human Rights, Terrorism \& Counter Terrorism", Fact Sheet No. 32, retrieved 14 August 2017, http://www.ohchr.org/Documents/Publications/Factsheet32EN.pdf,p.1

[16] League of Nation of Convention for the Prevention and Punishment of Terrorism, council on foreign relations, retrieved 15 August 2017 from http://www.cfr.org/terrorism-and-the-law/league-nations-convention-prevention-punishment-terrorism/p24778

[17] International Convention for the Suppression of Terrorism, retrieved $10 \quad$ August 2017 fromhttp://www.un.org/en/sc/ctc/docs/conventions/Conv11.pdf

[18] Human Rights and Terrorism, Icelandic Human Rights Centre, retrieved 12 February 2017 from humanrights.is/en/human-rights-educationproject/human-rights-concepts-ideas-and-fora/human-rights-in-relation-to-other-topics/human-rights-and-terrorism

[19] UN Security Council Resolution 1566, retrieved 15 August 2017 from www.cfr.org/international-organizations-and-alliances/un-securitycouncil-resolution-1566-terrorism/p11223

[20] UK Terrorism Act 2000, http://www.legislation.gov.uk/ukpga/2000/11/pdfs/ukpga_20000011_en.pdf

[21] U.S. 18 Code Chapter 113B, Terrorism, Legal Information Institute, Cornell University Law School, retrieved 15 August 2017 from https://www.law.cornell.edu/uscode/text/18/part-I/chapter-113B

[22] U.S. 18 Code Chapter 113B, Terrorism, Legal Information Institute, Cornell University Law School, retrieved 14 August 2017 from https://www.law.cornell.edu/uscode/text/18/part-I/chapter-113B

[23] Preamble of Universal Declaration of Human Rights, retrieved 10 January 2017 http://www.un.org/en/universal-declaration-human-rights/ 